\title{
E-book user behaviour in academic libraries: The role of user agents in perception and satisfaction
}

\author{
Pervaiz Ahmad $^{1}$ and Mark Brogan ${ }^{2}$ \\ ${ }^{1}$ Department of Library and Information Sciences, \\ Allama Iqbal Open University, Islamabad, PAKISTAN \\ ${ }^{2}$ School of Computer and Security Science, \\ Edith Cowan University, Perth, AUSTRALIA \\ e-mail: pervaiz@aiou.edu.pk (corresponding author); \\ mbrogan@iinet.net.au
}

\begin{abstract}
Based on technology adoption theories and allied frameworks, this paper aims to explore e-book user behaviour around multiple dimensions of the role of user agents in formation of patterns, attitudes, perception and satisfaction with electronic resources in an academic and research library context. A convenience sample of academics, staff, and students at Edith Cowan University (ECU) voluntarily self-reported their e-book information behaviour via online survey. In terms of agent/platform satisfaction, desktop computer and laptop/netbook had the most satisfied users. Significant factors in e-resource use and agents/platforms were found to include familiarity (collection awareness and differentiation between resource types), usability (discovery, information retrieval and readability, and library interface ease of use), utility (collection sufficiency), hedonic attributes (attractiveness), culture of use and habituation. Users satisfied with laptops/netbooks as user agents also expressed overall satisfaction with library e-books. E-book users' information behaviour was found to be consistent with major technology adoption theories and frameworks in terms of e-resources and their use platforms.
\end{abstract}

Keywords: E-books; Technology acceptance; User behaviour; Academic libraries; Research libraries; Electronic resources.

\section{INTRODUCTION}

The peer reviewed literature shows that academic libraries are rapidly transitioning from print to electronic collections and use of e-resources is increasing. Nicholas and White (2012) claim that students' demand for resources and services that are not limited by time and space is growing. Noh (2012) claimed that e-resources accounted for more than 50 percent of the overall budget of of Korean academic libraries. According to Armstrong and Lonsdale (2009), drivers in e-resource acquisition (including e-books) are distance education, short-loan or no-loan physical collections, need for multiple concurrent access, and advanced e-resource features and functions. Al, Soydal and Tonta (2010) argue that ebooks are forming a substantial part of library collection building. Guthrie (2012) argues that "transition to reliance on scholarly e-books will happen very quickly" (p. 353). Renner predicts that e-books, like e-journals, will be the norm in academia by the year 2020, and Sang-ho reports Korea's initiative to replace all paper textbooks in its schools with digital versions by 2015 (cited in Asunka 2013, p. 38). 
The picture with user acceptance is different and more nuanced. Safley (2006) argues that "while electronic journals are widely accepted by most academic library customers, the delivery of online books has had a very different acceptance rate" (p. 445). Pymm, Steed and Burless (2012) claimed that 2.9 million items were borrowed in 2011 by 1.9 million users of Libraries ACT (Australian Capital Territory). Of these borrowings, e-books or eaudio accounted for only a small percentage, despite an increase $(127.76 \%)$ in e-collection titles between 2006 and early 2012.

According to Moore, MacCreery and Marlow (n.d.), the relevance of a particular text in an electronic delivery platform must be considered in the context of the behaviours that it drives, not merely measured on how often it is accessed or how much time a patron spends reading it. Borchert et al. (2009) visualise the need for a theoretical framework to inform or summarise analysis of e-book adoption in Academic and Research Libraries (ARLs) particularly in an Australian context. D'Ambra and Wilson (2012) acknowledge that the University of New South Wales in Sydney is "... a large Australian university that has no strategy for the adoption of e-books by staff or students but had subscriptions to about 200,000 e-books in 2011" (p. 62).

\section{THEORETICAL LITERATURE AND FRAMEWORK}

So what factors shape e-book adoption outcomes? What does the research literature on technology adoption and information behaviour have to offer that informs understanding of e-book user behaviour? Exploration of the literatures shows that e-book adoption behaviour might be understood in terms of information behaviour theory, factors in human-computer interaction and other theories. This paper reviews e-book user behaviour broadly in the context of the literature on technology adoption theories and allied frameworks, developed originally as a tool for understanding adoption outcomes with new technologies.

Adapted from Fishbein and Ajzen's theory of reasoned action proposed in 1975, Fred D. Davis introduced the Technology Acceptance Model (TAM) in 1986 (Davis, Bagozzi, and Warshaw 1989). TAM holds that perceived usefulness, i.e. "the degree to which a person believes that using a particular system would enhance his or her job performance" and perceived ease-of-use i.e. "the degree to which a person believes that using a particular system would be free from effort", are two major determinants that explain computer usage behaviour and an individual's attitude and intention to use information technology (Davis 1989, p. 320). Whilst TAM would appear to have obvious potential as a tool for understanding e-book adoption, Letchumanan and Tarmizi (2011) note that "very few studies have investigated TAM as a model to explain the acceptance of the e-books" ( $p$. 517).

An evolution of TAM, namely Unified Theory of Acceptance and Use of Technology (UTAUT), also provides a framework for investigation. In 2003, a group of leading information systems researchers formulated the UTAUT model based on eight contemporary technology acceptance models including TAM (Venkatesh et al. 2003). UTAUT consists of four determinants of behavioural intention and use, namely, performance expectancy, effort expectancy, social influence and facilitating conditions. Venkatesh et al. define performance expectancy as "the degree to which an individual believes that using the system will help him or her to attain gains in job performance" ( $p$. 447). Effort expectancy is defined as "the degree of ease associated with the use of the 
system" (p. 450). Social influence is defined as "the degree to which an individual perceives that important others believe he or she should use the new system" (p. 451). Facilitating conditions are defined as "the degree to which an individual believes that an organizational and technical infrastructure exists to support use of the system" (p. 453). Additionally, the variables of gender, age, experience and voluntariness of use moderate the key relationships in the model (p. 447).

So how might TAM and UTAUT contribute to understanding of e-books? Whilst not explicitly linked to these frameworks, the literature on e-books emphasises performance expectancy or utility features that include comparative advantages of e-books over their print counterparts, content sufficiency and e-book effort expectancy (often operationalised in terms of usability) for the key functions of browsing and screen reading. Often untied to larger theoretical frameworks, discussion of advantages and disadvantages commonly occurs within the mainstream library and information science literature.

In discussion of TAM, Venkatesh (2000) points out two types of motivations, extrinsic and intrinsic. Extrinsic motivation refers to drive on the part of the use to achieve some goal or benefit. Perceived usefulness or utility is something brought to the experience of a system by the user and hence can be regarded as extrinsic. Intrinsic motivation is something affected by use of the system. For example, perceived pleasure and/or satisfaction is created when using a system. Since TAM does not explicitly include intrinsic motivations, Venkatesh proposed extensions to TAM. Among various constructs, computer playfulness and perceived enjoyment have been shown as important in shaping user's perceived ease of use. Computer playfulness may be viewed in terms of culture of use, for example, ebook use platforms and users' satisfaction with them. Hence, hedonic attributes may be applicable to perceived attractiveness of the e-book formats and overall pleasantness of ebook use experience.

In terms of the models presented as part of the theoretical discussion, 'Culture of use' seems close to Park's (2007) perspective of personal values. In this sense it refers to the prevailing common trend in devices and technologies that is, in part, socially defined. For example, use of smart phones as e-readers (Wood and Philips 2011), shared culture of using computing technologies such as social media, Internet and online resources, and habit/automaticity (Park 2007). Culture of use is sometimes referred to as e-culture, which means "the nature of intellectual life in a world of high-speed, global networks, intelligent services, and massive data - eCulture subsumes eScience, eResearch and other terms that describe formal academic work and includes phenomena such as wikis, blogs, video games" (Crane 2007, para. 1), and "all processes of expression, reflection and sharing in the digital domain" (Schwarz 2006, p. 2).

In UTAUT, the idea of facilitating conditions (called 'compatibility' in Innovation Diffusion Theory) encompasses environment factors such as organisational and technical infrastructure to support use of the system (Venkatesh et al. 2003). Such factors may include promotional and marketing activities (Vasileiou and Rowley 2011), training and information literacy instruction (ACRL 2013; Milliot 2007), findability, discovery, and connectivity (Konappa 2014; Shelburne 2009), access/referrer links/routes to e-books (Armstrong and Lonsdale 2009; Borchert et al. 2009; CIBER 2009) such as catalogue, metasearch and course lists.

Operationalisation of facilitating conditions in our research includes the dimensions of discovery, connectivity, and access routes to e-books such as catalogues, meta-search and 
course lists that may serve as intervening variables to understand e-book user experience and behaviour.

Familiarity (MacWilliam 2013; Shin 2011), or prior experience (Rowlands et al. 2007) and awareness (Ebrary 2008) also figure in fieldwork research on e-books. Shin (2001) citing Komiak and Benbasat defines familiarity as "one's understanding of technologies, often based on previous interactions, experience and learning of the what, who, how and when of what is happening" (p. 266). Hence, familiarity acquired with leisure reading of e-books on a Kindle or iPad, constitutes prior experience or interaction that may impact on attitude toward and use of ARL e-books and platforms.

Shin's (2011) use of the term 'familiarity' in his Uses and Gratification Expectancy (UGE) model of understanding e-book users aligns with the notion of prior experience based on repeated interactions. Awareness is a kindred but different notion suggesting the multidimensionality of 'familiarity'. Hence, familiarity in terms of prior experience of e-book use and awareness may also be considered important in e-book adoption. Other theories that might also be applicable include Expectation Confirmation Theory (ECT), and Uses and Gratifications Theory (UGT).

Expectation Confirmation Theory (ECT) suggests that consumers compare their expectation and perceived performance to form satisfaction. Confirmation is based on the actual performance judged by a user against expectation or pre-purchase standard. Perceived performance equalling or exceeding expectation leads to positive confirmation. The formation of subsequent behaviours, such as gratification and acceptance and engagement, is according to levels of confirmation (Mondi, Woods and Rafi 2008; Paragas et al. 2010; Shin 2011; Stafford, Stafford and Schkade 2004).

Uses and Gratifications Theory (UGT) is a model used in media research spanning user motivation studies ranging from different media to cell phones and the Internet. Gratifications are referred to as some aspect of satisfaction regarding the use of a particular medium based on users' feedback. Shin (2011) defines gratification as "some aspect of satisfaction reported by users, related to the active use of the medium in question" (p. 263).

UGT provides the framework for understanding user motivation to use a product or service. This approach focuses on what people do with media and why people use particular media, rather than on content as the main explanation of acceptance or rejection. The theory suggests that students make conscious and reasoned decision in selecting the media to satisfy their needs (Shin 2011). Tenopir (2010) is of the view that satisfaction is the ultimate measure of the success of library collections and services. ECT and UGT provide a framework that connects directly with Tenopir's idea. When perceived performance equals or exceeds expectation positive confirmation results, i.e. satisfaction. Satisfied users reuse or form an intention to reuse the product in future, whereas dissatisfied patrons do not (Bhattacherjee 2001). Shin asserts since the e-book interface has interactive features with high user involvement, the application of UGT to understand e-book user behaviour seems appropriate albeit with some adjustment in scales. 


\section{OBJECTIVES AND RESEARCH QUESTIONS}

This paper reports e-book user behaviour in academic libraries with reference to the role of user agents in formation of perception and satisfaction with electronic resources in a case study institution, Edith Cowan University, located in Western Australia. Particular objectives of the study are to find out:

a) the academic patterns of using electronic resources and platforms,

b) the level of satisfaction with e-book user agents,

c) user perception towards use of electronic resources and platforms, and

d) the association between satisfaction with e-book user agents and overall satisfaction with e-books.

Keeping in view the objectives the study addresses the following research questions along with description of independent and dependent variables (Table 1).

Table 1: Research Questions and Variables

\begin{tabular}{clcc}
\hline \hline No & \multicolumn{1}{c}{ Research questions } & \multicolumn{1}{c}{$\begin{array}{c}\text { Independent } \\
\text { variable }\end{array}$} & $\begin{array}{c}\text { Dependent } \\
\text { variable }\end{array}$ \\
\hline \hline 1 & $\begin{array}{l}\text { What patterns of electronic resources and } \\
\text { platforms' use exist in the case study academic and } \\
\text { research library? }\end{array}$ & N/A & N/A \\
2 & $\begin{array}{l}\text { What is users' level of satisfaction with e-book use } \\
\text { platforms? }\end{array}$ & N/A \\
3 & $\begin{array}{l}\text { How is users' perception towards use of electronic } \\
\text { resources and platforms formed? } \\
\text { Is there any association between satisfaction with e- } \\
\text { book user agents and overall satisfaction with e- } \\
\text { books? }\end{array}$ & $\begin{array}{l}\text { Satisfaction with e- } \\
\text { book user } \\
\text { agents/platforms }\end{array}$ & Satisfaction \\
with e-books
\end{tabular}

\section{METHOD}

This paper is based on self-reported information behaviour. A convenience sample was constructed of Edith Cowan University (ECU) academics, staff and students and a survey conducted after pilot testing in mid-2013. In total 315 responses fully or partially completed were retained for data analysis (scale reliability Cronbach's alpha $=0.72$ ).

Data were analysed statistically with Statistical Product and Service Solutions (SPSS) using (a) descriptive statistics and chi-square test for goodness of fit at $\alpha=0.05$, and (b) Pearson chi-square cross-tabulation at $\alpha=0.01$ (Monte Carlo). The Monte Carlo (MC) method with a 99 percent confidence interval (two-sided) was used in lieu of asymptotic 95 percent significance level $(\alpha=0.05)$ where (a) the expected cell frequencies lower than five were more than 20 percent (Allen and Bennett 2010), and (b) in accordance with IBM instructions with regard to computing exact significance level in SPSS (IBM, n.d). Effect size for each finding was also measured and findings with large to medium effect sizes are reported here. In case of Pearson chi-square test of contingencies effect size Phi $(\phi)$ is reported (Note: Phi and Cramer's $v$ will be identical for $2 \times \mathrm{k}$ design, while Cramer's v will be around half of Phi in kx k design). Cohen's $w$ is reported in case of chi-square test for goodness of fit. Effect size $<.3$ is small/weak, $=>.3$ and $<.5$ is medium/moderate, and $=>.5$ is large/strong (Allen and Bennett 2010, p. 228 \& 236). 
As noted, the survey of self-reported information behaviour was based on a convenience sample. As such, bias described low faculty and general staff participation and much stronger student participation based on new/fresh, young, on-campus, undergraduate, and Faculty of Health, Engineering and Science (FHES) and Faculty of Education and Arts (FEA) students. It was not possible to frame over 25,000 ECU population for random sampling, hence a non-probability technique (convenience sample) was used. Tanner (2013) claims that assumptions of normality in regard to the distribution of data do not apply if nonprobability sampling is selected. Consequently, this as well as categorical nature (Likerttype scaling) of the questionnaire data suggests the use of non-parametric procedures for inferential statistics (Sheard 2013). Allen and Bennett (2010) include Pearson Chi-square test of contingencies in non-parametric statistical procedures (p. 223 \& 230).

\section{RESULTS}

\section{RQ1. Patterns of Using Electronic Resources and Platforms}

A five-point scale from 1 (Never) to 5 (often, one or more times a day) with no labels for 2 , 3 , and 4 was used to assess how often the participants made use of various kinds of online resources and use media/platforms for online work of all kinds, not just e-books. Descriptive statistics (Mode) and chi-square test for goodness of fit with four (4) degrees of freedom at $\alpha=.05$ was used to test each item. Table 2 presents the statistics.

A chi-square test for goodness of fit test shows that responses for each platform/resource were statistically significantly different with large effect size for all except Library ejournals which had small effect.

Table 2: Use of Electronic Resources and Platforms: Goodness of Fit

\begin{tabular}{lcccccccccc}
\hline \hline E-resource & $\mathbf{r}$ & $\begin{array}{c}\mathbf{1} \\
\text { Never }\end{array}$ & $\mathbf{2}$ & $\mathbf{3}$ & $\mathbf{4}$ & $\begin{array}{c}\mathbf{5} \\
\text { Often }\end{array}$ & Mode & $\chi^{2}$ & $\begin{array}{r}\boldsymbol{p} \\
\text { Effect } \\
\text { size } \boldsymbol{w}\end{array}$ \\
\hline $\begin{array}{l}\text { Social media (e.g. Facebook, } \\
\text { Twitter, Youtube) }\end{array}$ & 296 & 44 & 42 & 34 & 49 & 127 & 5 & 99.03 & .000 & 0.58 \\
Online games & 296 & 142 & 56 & 35 & 23 & 40 & 1 & 154.24 & .000 & 0.72 \\
Library e-journals & 296 & 57 & 67 & 80 & 61 & 31 & 3 & 21.91 & .000 & 0.27 \\
\hline Platform/Agent & & & & & & & & & & \\
Laptop, netbook & 296 & 17 & 18 & 31 & 48 & 182 & 5 & 329.03 & .000 & 1.05 \\
Desktop computer & 296 & 51 & 44 & 34 & 37 & 130 & 5 & 108.76 & .000 & 0.61 \\
Smartphone & 296 & 64 & 28 & 21 & 27 & 156 & 5 & 217.28 & .000 & 0.86 \\
iPad & 295 & 149 & 19 & 29 & 24 & 74 & 1 & 204.24 & .000 & 0.83 \\
Tablet (other than iPad) & 295 & 205 & 27 & 24 & 10 & 29 & 1 & 455.36 & .000 & 1.24 \\
E-book reader & 296 & 195 & 43 & 33 & 15 & 10 & 1 & 401.43 & .000 & 1.16 \\
\hline \hline
\end{tabular}

The most frequently used platforms according to frequency of use (5-often) ranked (1) Laptop, netbook (61\%), (2) Smartphone (53\%), and (3) Desktop PC (44\%), while, the majority of respondents have never used a Tablet (other than iPad) (69\%), E-book reader (66\%), or iPad (51\%). Social media was the most widely used non-library information service (43\%). Survey respondents did not manifest propensity of playing online games with 48 percent claiming to never use them and only 13.5 percent using them often. With Library e-journals 19.26 percent of respondents claim never to use them with 31 percent recording behaviour suggestive of regular or frequent use. These findings are consistent with many previous studies. For example, in a survey of 121 undergraduate students at the Delta State University (USA) 20 percent of students self-reported as non- 
users of library e-journals (Enakrire and John 2012). Research Information Network's (2011) survey of academic cohorts in nine of the UK institutions (eight universities and a Government laboratory) regarding their attitudes towards e-journals found similar results. For example, academic community who self-reported as irregular or never-users of ejournals comprise 32.2 percent (undergraduates, Years 1 and 2), 11.8 percent (undergraduates, Years 3 and 4), 15.8 percent (taught postgraduate), 10.5 percent (PhD students), and 7.9 percent (researchers). In an Indian college survey of engineering and technology undergraduate students Dhanavandan, Esmail and Nagarajan (2012) found occasional use of e-resources including e-journals and around 18 percent of students were either unfamiliar or somewhat familiar with these resources.

\section{RQ2. Satisfaction with E-Book User Agents}

This part of the survey invited ECU or third party e-book users to assess their satisfaction level with e-book use media/platforms on a five-point scale $(r=\#$ of responses, $1=$ Very Unsatisfied, 2 = Unsatisfied, $3=$ Neutral, $4=$ Satisfied, $5=$ Very Satisfied). Descriptive statistics (Mode) and a chi-square test for goodness of fit with four (4) degrees of freedom at $\alpha=0.05$ were derived for each item (Table 3).

Table 3: Users' Satisfaction Level with E-book Use Platforms: Goodness of Fit

\begin{tabular}{lrrrrrrrrr}
\hline \hline Platform & r & 1- VU & 2-U & 3-N & 4-S & 5-VS & Mode & $\chi^{2}$ & $\boldsymbol{p}$ \\
\hline Laptop, netbook & 237 & 0 & 14 & 42 & 124 & 57 & 4 & 110.43 & .000 \\
Desktop PC & 230 & 2 & 10 & 63 & 93 & 62 & 4 & 130.13 & .000 \\
iPad & 221 & 6 & 12 & 113 & 48 & 42 & 3 & 164.00 & .000 \\
Smartphone & 218 & 15 & 50 & 92 & 45 & 16 & 3 & 90.95 & .000 \\
Tablet (other than iPad) & 210 & 6 & 12 & 143 & 31 & 18 & 3 & 311.76 & .000 \\
Kindle & 202 & 11 & 7 & 145 & 22 & 17 & 3 & 341.76 & .000 \\
Other e-book reader & 204 & 7 & 11 & 153 & 25 & 8 & 3 & 390.80 & .000 \\
Kobo & 198 & 13 & 9 & 164 & 5 & 7 & 3 & 489.37 & .000 \\
\hline \hline
\end{tabular}

A chi-square test for goodness of fit test showed that users' satisfaction level with each ebook use platform was statistically significantly different with large effect sizes for all platforms. According to descriptive statistics (Mode) and the effect size of chi-square goodness of fit test only laptop/netbook $(w=.68)$ and desktop PC $(w=.75)$ rated well in terms of user satisfaction. All other platforms showed ambivalent (neutral) responses and the results were found to be significant accordingly. In 2012-2013, agents other than laptop/netbook and desktop PC, did not provide a satisfying experience with library ebooks. The problem appears to be rooted in agent characteristics. For example, users of agents/platforms with small screen sizes demonstrated ambivalence.

\section{RQ3. Use of Electronic Resources/Platforms and User Perception}

Two kinds of data were used for this component of the study. Firstly, users were asked on an ordinal scale to self-assess their frequency of using electronic resources (online games, social media and e-journals) and their use media/platforms according to agent type (PC, laptop, tablet, iPad, smartphone, e-book reader) for online work of all kinds. Secondly, user perceptions of various dimension of the e-book experience were measured. Data in the perception section describe respondents' awareness and perception of ECU Library ebooks. A five-point Likert type scale ( 1 = Strongly Disagree, $2=$ Disagree, $3=$ Undecided, $4=$ Agree, $5=$ Strongly Agree) was used to measure the level of agreement/disagreement of participants against each item. The items on frequency of using e-resources and platforms 
were cross-tabulated using Pearson chi-square with 16 degrees of freedom with user perceptions. The analysis was expected to shed light on culture of use, facilitating conditions (UTAUT), utility and usability (TAM and UTAUT), familiarity (UGE), hedonic attributes (TAM), and information behaviour as moderated by agent type. The analysis consists firstly of crosstab results followed by findings. Table 4 presents the statistically significant results.

Table 4: Use of Electronic Resource/Platform vs. Perception/Attitude: Crosstabs

\begin{tabular}{|c|c|c|c|c|c|c|}
\hline \multirow[t]{2}{*}{ No } & \multirow{2}{*}{$\begin{array}{l}\text { E-Resource / } \\
\text { Platform } \\
\text { (Frequency of use) }\end{array}$} & \multirow[t]{2}{*}{ Perception/Attitude } & \multicolumn{4}{|c|}{ Pearson Chi-square statistics } \\
\hline & & & $\mathrm{n}$ & $\chi^{2}$ & $\begin{array}{r}\text { Sig } \\
(M C)\end{array}$ & $\begin{array}{l}\text { Effect } \\
\text { Size } \varphi\end{array}$ \\
\hline 1 & $\begin{array}{l}\text { Desktop } \\
\text { Computer }\end{array}$ & The ECU Library has e-books in its collection & 202 & 35.64 & .004 & .42 \\
\hline 2 & $\begin{array}{l}\text { Library } \\
\text { e-journals }\end{array}$ & $\begin{array}{l}\text { The Library interface for finding e-books is } \\
\text { easy to use }\end{array}$ & 263 & 36.73 & .002 & .37 \\
\hline 3 & $\begin{array}{l}\text { Library } \\
\text { e-journals }\end{array}$ & $\begin{array}{l}\text { I have experienced problems accessing } \\
\text { Library e-books over the Internet }\end{array}$ & 287 & 39.91 & .001 & .37 \\
\hline 4 & $\begin{array}{l}\text { Library } \\
\text { e-journals }\end{array}$ & The Library e-book text window is too small & 285 & 39.99 & .001 & .38 \\
\hline 5 & $\begin{array}{l}\text { Desktop } \\
\text { Computer }\end{array}$ & $\begin{array}{l}\text { Searching e-books for the information I need } \\
\text { is easy }\end{array}$ & 203 & 35.80 & .003 & .42 \\
\hline 6 & $\begin{array}{l}\text { Library } \\
\text { e-journals }\end{array}$ & $\begin{array}{l}\text { Current Library e-book collections satisfy my } \\
\text { needs }\end{array}$ & 270 & 36.04 & .003 & .37 \\
\hline 7 & $\begin{array}{l}\text { Library } \\
\text { e-journals }\end{array}$ & Library e-book formats are attractive & 287 & 34.92 & .004 & .35 \\
\hline 8 & E-book reader & Typically, I skim read Library e-books & 203 & 52.90 & .001 & .51 \\
\hline 9 & $\begin{array}{l}\text { Library } \\
\text { e-journals }\end{array}$ & E-books and e-journals are different & 289 & 44.71 & .000 & .39 \\
\hline
\end{tabular}

Serial-wise interpretation of results in Table 4 and their contingency tables is as follows:

a) Frequent desktop computer users were more likely to be aware of ECU Library ebooks. The effect showed medium level strength. The peer reviewed literature is also supportive of desktop computer as a preferred agent for using e-books (e.g. Nicholas, Rowlands and Jamali 2010). The preferred agents for viewing library e-books in this study are desktop computer and laptop. The explanation is inclusive of usability factors (TAM/UTAUT) such as screen size.

b) Users of Library e-journals are more likely to find the Library interface for finding e-books easy to use. Library e-journals are routinely used by students and academics. In the Library's OneSearch interface, e-journals appear in results lists and e-books are signposted as a format in the results list, describing a common point of entry. More broadly this medium strength association suggests that users comfortable with the discovery interface for journal searching find this an efficient interface for accessing ebooks as well. This points to the importance of facilitating conditions in technology adoption and habituation to e-resources.

c) Users of Library e-journals at any level $(n=234)$ who experienced no access problems with Library e-books over the Internet were more $(111,47.44 \%)$ than those who experienced problems $(83,35.47 \%)$ or were undecided $(40,17.09 \%)$. The effect had 
medium level strength. Finding suggests that users who are efficient at connecting with one resource are likely to be efficient at connecting with other resources. In other words, where users identify an issue (or no issue) with facilitating conditions with one electronic format (e.g. e-journals), this is also likely to apply to another (e.g. e-books). Analysis is consistent with the observation that in practical terms, issues with platforms and connections will likely affect both formats in a similar manner. Other explanation includes accessing a shorter length journal article might be less problematic than accessing a whole e-book of longer length, especially if Internet speed plays a role (JISC 2009). Previous research has also highlighted e-book access issues such as unsmooth browsing, accessing page-by-page, error messages and lockout in rapid paging, and latency (Armstrong and Lonsdale 2009).

d) Users of Library e-journals largely disagreed that the e-book text window was too small. Since the e-journal is a mature and well-accepted format it appears that users of e-journals are well adapted to online formats including e-books, i.e. users who find ejournals usable in terms of window size, are not likely to be troubled by this with ebooks. This points to the importance of culture of use and usability (UTAUT/TAM) in technology adoption. The preferred agents/platforms for viewing library e-books are desktop computer and laptop. The explanation is inclusive of usability factors such as screen size.

e) Desktop computer users found searching e-books for the information they need easy. In this study, the laptop and desktop computer are the preferred platforms for using e-books. Searching an e-book on desktop computer with a large display, involves better usability and hence less frustration to users. The effect had medium level strength. The finding points to the importance of usability and culture of use in technology adoption.

f) Often and frequent users of e-journals largely agreed about the Library e-book collection sufficiency. The effect had medium level strength. The finding suggests that users who are receptive to or seek out e-journals are efficient at connecting with ebooks and hence are more likely to be satisfied with collections. Information literacy required for efficient use of e-journals is similar to e-books. The finding is an endorsement of culture of use (user preference for online resources), and utility, since e-journals and e-books commonly appear together in results lists.

g) Often and frequent users of e-journals largely agreed that the Library e-book formats were attractive. The effect had medium level strength. Thus users satisfied with the ejournal experience are more likely to be satisfied with the e-book experience in terms of perceived pleasantness. The finding is consistent with the similarity of the formats and endorses the idea of hedonic attributes as important in acceptance. It is also a reflection on habituation and culture of use.

h) Findings show that no or infrequent users of e-book readers typically skim read Library e-books. Respondents who self-reported as frequent users of e-book readers were less likely to self-report as skim readers. The effect size was large. The result suggests that habituation in reading habits can grow from platform characteristics and shape information behaviour. Peer reviewed literature shows that e-book readers are typically used for leisure/fictional, linear reading (e.g. Browne and Coe 2012); also consistent with an open-ended comment in our survey "I use a kindle for 'recreation reading' and laptop for accessing library ebooks for uni coursework \& assignments." Browne and Coe further note that current academic/non-fiction e-books are less successful where navigation through browse, search, and indexes is crucial, and where complex formatting (e.g. tables, figures, and sidebars) may make it difficult. The finding is an endorsement of automaticity/habituation and culture of use. 
i) Users of e-journals were more likely to differentiate e-book and e-journals. This is consistent with earlier finding as users of both the formats are in a better position to know the difference between both the resources. Information literate users of information sources are equipped at making this distinction.

\section{RQ4. Satisfaction with E-Book User Agents and Overall Satisfaction with E-books}

In previous section, it was described how users were invited on a Likert scale to rate their satisfaction with various user agents (desktop computers, laptops, tablets and e-book readers). The investigation showed strong preference for desktop computers and laptops. The investigation in this section is based on a chi-square cross-tabulation of satisfaction between e-book use platforms ( 1 = Very Unsatisfied, $2=$ Unsatisfied, $3=$ Neutral, $4=$ Satisfied, $5=$ Very Satisfied) and perception of overall satisfaction with ECU e-books ( $1=$ Strongly Disagree, 2 = Disagree, 3 = Undecided, 4 = Agree, 5 = Strongly Agree). Confirmation of the earlier finding was obtained with statistically significant association found between satisfaction with laptop/netbook and satisfaction overall with ECU e-books $\left(\mathrm{n}=196, \mathrm{df}=12, \chi^{2}=42.26, \mathrm{MC}\right.$ sig $=.000, \varphi=.46$, medium). Of 153 users satisfied with laptop/netbook, 122 (79.74\%) were also satisfied with ECU e-books (sum of response values 4 and 5 of both the variables). The finding shows that users satisfied with laptop, netbook as a user agent were likely to be satisfied overall with ECU e-books. The effect of the relationship had medium-sized strength. The finding endorses culture of use, usability (TAM/UTAUT), confirmation (ECT), and gratification (UGT) as important in user acceptance and engagement of e-books.

\section{DISCUSSIONS}

Data analysis of self-reported behaviour showed that users were more satisfied with desktop PC $(w=.75)$ and laptop $(w=.68)$ as library e-book use platforms. At this point in time, smartphones, tablets and e-book readers do not provide a satisfying viewing experience with library e-books yielding ambivalent (neutral) responses.

Wells and Dumbell (2010), citing Safley (2006), argue that platforms may lead to e-books being used more often and e-book usage is also influenced by the different access models provided by different platforms (p. 2). MacWilliam (2013) claims that "the user experience rests not just in the e-book but on the device that the e-book is read" (p. 1). He further explains that a variety of e-reader devices has given rise to diverse levels of design and interactivity, for example, e-book, enhanced e-book and e-book app. He concludes that "publishers can affect the e-book contents and further enhance the reader's experience" and in this regard, they need to think innovatively and use a human-centred approach to design for more engaging experiences. The use of e-book readers also provides additional elements of playfulness (a hedonic attribute) and curiosity which is likely to motivate users to use e-books.

Prior studies demonstrated mixed results. For example, Croft and Davis (2010) found laptop (91.1\%) and Blackberry smartphone (36.4\%) as the most frequently used devices by students both for general and particular (e-book) use. While others (e.g. Khan, Ahmed and Masrek 2014) measured overall satisfaction of research students in one construct (inclusive of all types of library and open-access e-resources) with pre-determined parameters (accuracy of information, file formats, interface, download speed, help function on homepage, browsing facility, and display of search results) using descriptive statistics. 
Broadhurst and Watson (2012) argue that "students also agreed that even if they were supplied with an iPad or other tablet PC, they would still want laptops for other study purposes as it would not fulfil all of the functions required for their day-to-day study" (p. 175). In their survey of distance university students, Brahme and Gabriel (2012) reported that "no participants preferred reading on a tiny, smartphone-sized screen" (p. 190). After two trials of seven, popular e-book readers by staff and students followed by discussion Huthwaite et al. (2011) found that no device could come up to the expectations against the pre-determined criteria of usability, functionality, accessibility and compatibility with Queensland University of Technology Library's e-book collection and DRM issues.

Richardson and Mahmood's (2012) evaluation of user satisfaction and usability concerns related to five of the leading e-book readers (Amazon's Kindle, Apple's iPad, Barnes \& Noble's Nook, Borders' Kobo, and Sony's Digital Reader) through a survey of 81 information studies graduate students at the University of California found that despite having advantage of portability and multiple books the respondents were unsatisfied with the navigation, loaning, and licensing of titles. Schomisch, Zens and Mayr (2013) with regard to user test of Amazon Kindle 2, Sony Reader, Onyx Boox, and Apple Tablet PC iPad assert that "... e-readers do not yet fit seamlessly into the established chain of scholarly text-processing..." (p. 388).

Difficulties with on-screen reading of e-books is a usability issue also reported in previous studies (Borchert et al. 2009; JISC 2009; Li et al. 2011). Effort is not only an agent form factor issue. According to Browne and Coe (2012), current academic/non-fiction e-books are less successful for linear reading where complex formatting (e.g. tables, figures, and sidebars) may make navigation through the work difficult. Chong, Lim and Ling (2009) citing Chowdhury argue that interface design has an impact on usability (p. 213). They further argue that unsatisfactory e-book design is a barrier to student uptake of e-books and three design areas, navigation design, page layout, and content design, need improvement. Hence the form/genre of the e-book itself can also impact on usability with adverse impact on viewing effort.

Some other survey findings in this study endorsed earlier findings as well. For example, since laptops and desktops were most widely used platforms, respondents in this study did not find e-books hard to read on their screens $(w=.63)$. Users agreed that the Library ebook text window was not too small $(w=.73)$ (further endorsed by cross-tabulation, $\phi=$ .34). The analysis also showed that the laptop and desktop PC agents, as the preferred ebook use platform, were well suited to the typical user requirements of skim reading ( $w=$ .99 ) and fact finding $(w=.99)$ in the book body, i.e. outside the table of contents pages ( $w$ $=.81)$.

\section{CONCLUSION}

How platforms and interfaces can be adjusted to improve user acceptance is not a green field, but populated with examples that point the way forward. Industry experience and findings from this research point to the desirability of reader education, wider agent/medium compatibility (culture of use), and interface innovation in building wider ebook acceptance in ARLs.

For example, the success of the Amazon's Kindle, a device which "looks and reads like real paper" points to the importance of verisimilitude and also usability; compared with LCD 
technology, e-ink screens offer $50 \%$ better contrast (Amazon, 2010, para. 5). Goodwyn (2014) argues that e-book readers (such as Kindle) reproduce the look of a traditional book with black print on a white surface/screen. While some studies (e.g. Zimerman 2011) highlight the features of other e-book readers including Apple's iPad as well. Furthermore, Lai and Chang (2011) argue that the advantages of using dedicated e-book readers include "convenience (the ability to use it anywhere and anytime), compatibility (approximating the book experience), and media richness (hyperlinking) ... stand-alone capability (no computer required), fast downloading, thin cases, large storage capacity, and access by either wired or wireless Internet" (p. 559).

Results showed that users who experience e-books on Ebook Library (EBL) and Ebrary type platforms with desktop and laptop agents typically skim read Library e-books, while frequent users of e-book readers are much less likely to skim read ( $\phi=.51$ ). This result suggests that habituation in reading habits can grow from platform characteristics and shape information behaviour. Implications therefore of failure to address issues with platforms and interfaces may be seen to extend beyond rejection and acceptance, but also to information behaviour where existing interfaces promote shallow involvement with e-book content. This study has forged new knowledge of the connection between e-book experience on other platforms and how this shapes use of e-books in an academic library context. A key tactic in interface innovation is individualisation, comprising personalisation and customisation.

This study encompasses multiple dimensions of e-book user behaviour mainly focusing on user agents and may be useful to those who intend to research in the similar direction.

\section{ACKNOWLEDGEMENT}

This research received no specific grant from any funding agency in the public, commercial, or not-for-profit sectors.

\section{REFERENCES}

ACRL (Association of College \& Research Libraries). 2013. Introduction to information literacy. Available at: http://www.ala.org/ala/mgrps/divs/acrl/issues/infolit/ overview/intro/index.cfm\#what.

Allen, P. and Bennett, K. 2010. PASW statistics by SPSS: A practical guide: Version 18.0. Melbourne: Cengage Learning.

Al, U., Soydal, I. and Tonta, Y. 2010. Analysis of e-book use: The case of Ebrary. Proceedings of the 14th International Conference on Electronic Publishing pp. 315-329. Helsinki, Finland: Hanken School of Economics.

Amazon. 2010. Announcing a new generation of Kindle: The all-new Kindle is smaller, lighter, and faster, with 50 percent better contrast [Press release]. Available at: http://phx.corporate-ir.net/phoenix.zhtml?c=176060\&p=irolnewsArticle\&ID=1453463\& highlight=.

Armstrong, C. and Lonsdale, R. 2009. E-book collections management in UK universities: focus group report (final report). JISC National E-books Observatory Project. Available at: http://www.jiscebooksproject.org/reports. 
Asunka, S. 2013. The viability of e-textbooks in developing countries: Ghanaian university students' perceptions. Open Learning: The Journal of Open, Distance and e-Learning, Vol. 28: no. 1, 36-50.

Bhattacherjee, A. 2001. Understanding information systems continuance: An expectationconfirmation model. MIS Quarterly, Vol. 25 no. 3: 351-370.

Borchert, M., Hunter, A., Macdonald, D. and Tittel, C. 2009. A study on student and staff awareness, acceptance and usage of e-books at two Queensland universities. Available at: http://eprints.usq.edu.au/4876/.

Brahme, M. and Gabriel, L. 2012: Are students keeping up with the e-book evolution? are ebooks keeping up with students' evolving needs?: Distance students and e-book usage, a survey. Journal of Library \& Information Services in Distance Learning, Vol. 6, no. 3-4: 180-198.

Broadhurst, D. and Watson, J. 2012. E-book readers for full-time MBA students: An investigation in Manchester. Journal of Business \& Finance Librarianship, Vol. 17, no. 2: 170-182.

Browne, G. and Coe, M. 2012. Ebook navigation: Browse, search and index. Australian Library Journal, Vol. 61: no. 4, 288-297.

Chong, P. F., Lim, Y.P. and Ling, S. W. 2009. On the design preferences for Ebooks. IETE Technical Review, Vol. 26, no. 3: 213-222.

CIBER. 2009. Scholarly e-book usage and information seeking behaviour: A deep log analysis of MyiLibrary (final report). JISC National E-books Observatory Project. Available at: http://www.jiscebooksproject.org/reports.

Crane, G. 2007. eCulture, cyberinfrastructure, virtual research environments and the cultural heritage of the Maghreb. Paper presented at the Implementing a Maghreb Digital Library for Education, Science and Culture Conference, Rabat, Morocco, 25-28 Jan 2007.

Croft, R. and Davis, C. 2010. E-books revisited: Surveying student e-book usage in a distributed learning academic library 6 years later. Journal of Library Administration, Vol. 50, no. 5: 543-569.

D'Ambra, J. and Wilson, C. S. 2013. Application of the task-technology fit model to structure and evaluate the adoption of e-books by academics. Journal of the American Society for Information Science and Technology, Vol. 64, no. 1: 48-64.

Davis, F. D. 1989. Perceived usefulness, perceived ease of use, and user acceptance of information technology. MIS Quarterly, Vol. 13, no. 3: 319-340.

Davis, F. D., Bagozzi, R. P. and Warshaw, P. R. 1989. User acceptance of computer technology: A comparison of two theoretical models. Management Science, Vol. 35, no. 8: 982-1003.

Dhanavandan, S., Esmail, S. M. and Nagarajan, M. 2012. Use of electronic resources at Krishnasamy College of Engineering \& Technology Library, Cuddalore. Library Philosophy and Practice, paper 698.

Ebrary. 2008. 2008 global student e-book survey. Available at: http://www.ebrary.com/corp/collateral/en/Survey/ebrary_student_survey_2008.pdf.

Enakrire, R. T. and John, E. O. 2012. The attitude of undergraduate students towards the use of journals in Delta State University Library, Abraka, Delta State. International Journal of Library Science, Vol. 1, no. 2: 28-37.

Goodwyn, A. 2014. Reading is now "cool": A study of English teachers' perspectives on ereading devices as a challenge and an opportunity. Educational Review, Vol. 66, no. 3: 263-275.

Guthrie, K. M. 2012. Will books be different? Journal of Library Administration, Vol. 52, no. 5: 353-369.

Huthwaite, A., McClintock, A., Sinnamon, B. and Sondergeld, P. 2011. Ebook readers: Separating the hype from reality. Paper presented at the ALIA Information Online Conference, Sydney, Australia, 1-3 Feb 2011. 
IBM. (n.d.). Method subcommand (crosstabs command). Available at: http://pic.dhe.ibm.com/infocenter/spssstat/v20r0m0/index.jsp?topic=\%2Fcom.ibm.spss .statistics.help\%2Fsyn_crosstabs_method.htm.

JISC. 2009. JISC national e-books observatory project: Key findings and recommendations (final report). JISC National E-books Observatory Project. Available at: http://www.jiscebooksproject.org/reports.

Khan, A., Ahmed, S. and Masrek, M. N. 2014. Scholars' satisfaction with digital library collection and gaps in the provision of effective information resources and services: $A$ Pakistani perspective. Journal of Electronic Resources Librarianship, Vol. 26, no.4: 250267.

Konappa, K. 2014. Use of electronic information resources in university libraries of Tirupati (A.P): An analytical study. International Journal of Library and Information Science, Vol. 6, no. 1: 5-13.

Lai, J. and Chang, C. 2011. User attitudes toward dedicated e-book readers for reading: The effects of convenience, compatibility and media richness. Online Information Review, Vol. 35, no. 4: 558-580.

Letchumanan, M. and Tarmizi, R. A. 2011. Assessing the intention to use e-book among engineering undergraduates in Universiti Putra Malaysia, Malaysia. Library Hi Tech, Vol. 29, no. 3: 512-528.

Li, C., Poe, F., Potter, M., Quigley, B. and Wilson, J. 2011. UC libraries academic e-book usage survey: Springer e-book pilot project. Available at: http://www.cdlib.org/services/uxdesign/docs/2011/academic_ebook_usage_survey.pdf

MacWilliam, A. 2013. The engaged reader: A human-centred evaluation of ebook user experience. Publishing Research Quarterly, Vol. 29, no. 1: 1-11.

Milliot, J. 2007. E-books need visibility. Publishers Weekly, Vol. 254, no. 28: 16.

Mondi, M., Woods, P. and Rafi, A. 2008. A uses and gratification expectancy model to predict students' perceived e-learning experience. Educational Technology \& Society, Vol. 11, no. 2: 241-261.

Moore, W., MacCreery, N. and Marlow, M. (n.d.). Usage measurements for digital content: White paper. Available at: http://www.springer.com .

Nicholas, D., Rowlands, I. and Jamali, H. R. 2010. E-textbook use, information seeking behaviour and its impact: Case study business and management. Journal of Information Science, Vol. 36, no. 2: 263-280.

Nicholas, P. and White, T. 2012. E-learning, e-books and virtual reference service: The nexus between the library and education. Journal of Library \& Information Services in Distance Learning, Vol. 6, no. 1: 3-18.

Noh, Y. 2012. A study measuring the performance of electronic resources in academic libraries. Aslib Proceedings: New Information Perspectives, Vol.64, no. 2: 134-153.

Paragas, F. D. C., Clara, D. Y., Main, L. T. and Rahman, N. B. A. 2010. Mobile telephony uses and gratifications among elderly Singaporeans. Media Asia, Vol.37, no. 4: 215-243.

Park, S. H. 2007. Role of personal values in acceptance of information technology (Doctoral dissertation). ProQuest Dissertations and Theses database. (UMI No. 3280345).

Pymm, B., Steed, S. and Burless, M. 2012. E-books, e-audio and public libraries: Is it lift off or steady as she goes? Libraries in the Digital Age (LIDA) Proceedings (vol. 12). Available at: http://ozk.unizd.hr/proceedings/index.php/lida/article/view/9/17.

Research Information Network. 2011. E-journals: Their use, value and impact: Final report. Available at: http://ciber-research.eu/download/20110119-E-journals-phase2.pdf.

Richardson, J. V. and Mahmood, K. 2012. Ebook readers: User satisfaction and usability issues. Library Hi Tech, Vol.30, no. 1: 170-185. 
Rowlands, I., Nicholas, D., Jamali, H.R. and Huntington, P. 2007. What do faculty and students really think about e-books? Aslib Proceedings: New Information Perspectives, Vol. 59, no. 6: 489-511.

Safley, E. 2006. Demand for e-books in an academic library. Journal of Library Administration, Vol. 45, no. 3-4: 445-457.

Schomisch, S., Zens, M. and Mayr, P. 2013. Are e-readers suitable tools for scholarly work? Results from a user test. Online Information Review, Vol. 37, no. 3: 388-404.

Schwarz, M. 2006, October. e-culture: Crossovers and challenges. Paper presented the eCulture Trends 06 Symposium, Fraunhofer Institute for Intelligent Analysis and Information Systems, Bremen, Germany, 20 Oct 2006.

Sheard, J. 2013. Quantitative data analysis. In K. Williamson \& G. Johanson (Eds.), Research methods: Information, systems and contexts (pp. 395-416). Prahran, Victoria: Tilde University Press.

Shelburne, W. A. 2009. E-book usage in an academic library: User attitudes and behaviors. Library Collections, Acquisitions, \& Technical Services, 33, 59-72.

Shin, D. 2011. Understanding e-book users: Uses and gratification expectancy model. New Media \& Society, Vol. 13, no. 2: 260-278.

Stafford, T. F., Stafford, M. R. and Schkade, L.L. 2004. Determining uses and gratifications for the Internet. Decision Science, Vol. 35, no. 2, 259-288.

Tanner, K. 2013. Survey designs. In K. Williamson \& G. Johanson (Eds.), Research methods: Information, systems and contexts (pp. 141-171). Prahran, Victoria: Tilde University Press.

Tenopir, C. 2010. Online databases: Usage and functionality. Library Journal, Vol. 135, no. 3 : 21.

Vasileiou, M. and Rowley, J. 2011. Marketing and promotion of e-books in academic libraries. Journal of Documentation, Vol. 67, no. 4: 624-643.

Venkatesh, V. 2000. Determinants of perceived ease of use: Integrating control, intrinsic motivation, and emotion into the technology acceptance model. Information Systems Research. INFORMS, Vol. 11, no. 4: 342-365.

Venkatesh, V., Morris, M. G., Davis, G. B. and Davis, F. D. 2003. User acceptance of information technology: Toward a unified view. MIS Quarterly, Vol. 27, no. 3: 425-478.

Wells, D. and Dumbell, P. 2010, February. Ebook usage at Curtin University Library: Patterns, projections and strategy. Paper presented at the VALA2010 15th Biennial Conference and Exhibition, Melbourne, Australia, 9-11 Feb 2010.

Wood, G. and Philips, J. 2011. Using smartphones in health - what are the implications for library resources? Paper presented at the ALIA Information Online Conference, Sydney, Australia, 1-3 Feb 2011.

Zimerman, M. 2011. E-readers in an academic library setting. Library Hi Tech, Vol. 29, no. 1: 91-108. 